\title{
To Protect or Not to Protect- Tariffs in Small Countries: Evidence From Egypt
}

\author{
Mayar Bakeer \\ The German University in Cairo \\ Hebatallah Ghoneim \\ The German University in Cairo
}

In a world promoting free trade, policies aim to increase economic welfare. Nevertheless, the impact of decreasing protectionism on small countries has been unclear. The aim of this research is to evaluate the effect of decreasing tariff rates on welfare in small developing countries, using Egypt as a case study. This is done through simulating the tariff rates imposed by the Egypt-European Union Association Agreement (E-EUAA), which calls for tariff rates to be gradually decreased until they reach zero. The results show that the lower the protectionism, the lower the welfare, which is attributed to low export levels within the country and high prices.

Keywords: CGE simulation, Trade Policy, EU, unemployment, consumer welfare

\section{INTRODUCTION}

Expansion of international trade has always been a major political concern. The World Trade Organization (WTO) has encouraged trade liberalisation to enhance the economies of the world, usually by decreasing or eliminating formal forms of protectionism, including tariffs. Increasing trade liberalisation integrates the global economy, which improves market efficiency and economic welfare (Adegboye, Matthew, \& Ejemeyovwi, 2020).

Previous literature has disputed the effects of protectionism on small countries, as it may have a counter effect on economic welfare. Arguments on the topic have varied, ranging from the importance of protecting domestic infant industries within a country to the importance of free trade to inducing economic growth (Zaki, 2010; Krugman, Obstfeld, \& Melitz, 2015).

The aim of this research is to test the effect of protectionism on small countries, which are countries that have no influence over world price, and measure the impact on economic welfare. Egypt will be used as an example of a small developing country; to aid in making the model realistic, protectionism shall be applied by using the terms of the Egyptian-European Union Association Agreement (E-EUAA), which will provide insight into how European Union Association Agreements (EUAA) can affect economic welfare in small countries.

This paper will use a Computable General Equilibrium (CGE) model to simulate the effect of protectionism on economic welfare by gradually decreasing the tariff rates to zero as per the E-EUAA agreement. The results show that a decrease in tariff rates causes a fall in the GDP; this can be attributed to 
a decline in aggregate exports caused by the inability of low-quality Egyptian goods to compete in the international market. The research also highlights the influence of unemployment. The impact of high unemployment does not change with the tariff rates; however, it does cause a change in the final output, in turn changing the magnitude and direction caused by decreasing tariff rates.

The outcome of this study shows another angle not often seen in mainstream economics. Previous literature argues that trade liberalisation helps increase economic welfare. Nevertheless, the outcome may differ the case of small developing countries, as these economies are not ready to fully mingle with the relatively larger countries, especially domestically, making the welfare in these countries actually decrease (Salvatore, 2020; Konan, 2000).

The paper is organized as follows. The first section will tackle tariffs and protectionism in small developing countries, followed by an overview of Egypt and an explanation of why it was chosen for this study. The second section will focus on the model, starting with previous studies of trade protectionism in small developing countries, then the model specifications. The results will be detailed in the final section, accompanied by the conclusion and policy implications.

\section{Trade Protectionism Versus Liberalisation Dilemma}

Trade policies are one factor that may cause an economy to rise or fall; they affect the production and the goods available within a country and the extent to which it depends on itself or others. As a result, they should be well planned and regulated (Noll, 1997). Tariffs are one of the commonly used tools for protectionism in small countries; they make the prices of the tariffed commodity higher than the world price, decreasing demand and thus imports. This makes producers better off: it gives a chance for domestic production of the product to bloom and compete with international goods (Salvatore, 2020; Obstfeld \& Melitz, 2015).

Relaxing trade policies or decreasing protectionism allows a smoother flow of goods and services within the economy; this helps exporters and producers open foreign markets and obtain those profits. In addition, it increases competition and drives import prices lower, which enhances the welfare of the consumer. On the other hand, some researchers have promoted protectionism, arguing that it improves local industries by protecting them from foreign competitors and thus allows them space to generate high income and profits. In this view, protectionism secures equal competition for domestic firms against international ones, which may drive them out of the market, as well as a source of government revenue, thus affecting welfare in the economy (Altschiller, 1988; Salvatore, 2020; Feraboli, 2007).

Nevertheless, distortions in the economic welfare of the state are one of the recurring consequences of protectionism, which is why free trade is more invigorated (Konan \& Maskus, 2000; Braga de Macedo \& Martins, 2006).

\section{Small Countries}

A small country is one that has no influence over world prices. When a small country is involved in trade, the volume and terms of trade are significantly different than they are for a large country. Typically, the burden of protectionism will be mostly, if not entirely, on the small country, and the same applies to liberalisation (Krugman, Obstfeld, \& Melitz, 2015).

According to most trade theories, trade is a game of mutual benefit, and it has an impact on both players. Due to the discrepancy in the trade volume, this is most likely to cause distortions in the final output of economic welfare (Konan \& Maskus, 2000).

The highest impact a tariff has on small countries is that on domestic prices, which would impact the prices of exports as well. Although liberalisation causes the distortion to clearly decrease, the composition of imports does matter, namely, whether they are mostly raw materials or final goods. The former might cause a decrease in economic welfare, as protectionism in this case would not be effective, while the latter will induce an increase in welfare (Krugman, Obstfeld, \& Melitz, 2015).

This sheds light on the importance of exploring the impact of protectionism on small countries and the possible distortions that may occur. 


\section{The Case of Egypt}

Egypt is considered a small country that has no influence on world prices (Fahmy, 2012), though it has strong trade relations with neighboring countries and is considered a resource-rich country. Nevertheless, beginning in the early 1960s, Egypt faced various trade policy orientations with diverse rules and consequences, leaving it with a 5.55\% GDP growth rate and exports representing $-2.14 \%$ of the GDP as of 2019 , numbers that categorize it as a developing country according to the World Bank (World Databank, 2020). The composition of imports in the Egyptian economy are also worth mentioning: $75 \%$ of imports are directed to the manufacturing sector, which makes them of primary nature one way or another (according to the division of goods and services in the model) (World Databank, 2020). This makes Egypt a good case study to represent the effect of protectionism on a small developing country and simulate the effect of eliminating barriers (Ikram, 1980; World Databank, 2020; Kheir el Din, 2008).

Egypt has historically used tariffs. Tariffs reached $25.1 \%$ in 1995 before rocketing to $40.9 \%$ in 2002 . The Egyptian-European Association Agreement (E-EUAA) decreased tariffs by $25 \%$ upon its execution in 2004 and decreased them by a further $19 \%$ in 2005 . The agreement denoted full exemption of custom duties and an application of an ad valorem tariff to all agricultural products exported from Egypt. Meanwhile, EU exports to Egypt were granted an elimination of custom duties and a tariff reduction of 5\% two years into the agreement, $15 \%$ after three years, $25 \%$ after four years, and finally reduction to a $0 \%$ tariff rate on all other duties thereafter. Such trade liberalisation, or decrease in protectionism, is expected to increase the welfare in Egypt. Nevertheless, it could clash with governmental policies, as a decrease in government revenue will occur due to a deficiency in protectionism. Thus, whether the country's economic welfare will actually increase or not is trivial (EU Agreement, 2004; Elshennawy, 2012; Feraboli, 2007, Burfisher, 2021; Bandara, 1991).

The purpose of this paper is to investigate the effect of protectionism on small countries. This will be done by testing the effect of gradually lowering and eventually eliminating tariffs on Egyptian agriculture and manufacturing goods as prescribed by the E-EUAA agreement with Egypt. As tariffs are gradually removed, the effect on the welfare of the Egyptian economy will be calculated in order to measure the magnitude of the impact.

\section{PREVIOUS FINDINGS}

Computable general equilibrium models have proven to be an efficient method to test for the impact of trade liberalisation and protectionism by simulating changes within the model. The following section will discuss previous research examining simulations made on small developing countries and the impact of trade protectionism or liberalisation through CGE models.

Siddiqui (2007) tested the effect of full and partial liberalisation of rice and agricultural trade on economic welfare and poverty in Pakistan. A computable general equilibrium analysis was conducted to segregate the labor to agricultural and non-agricultural. The proxies observed were the equivalent variation for welfare and the Foster-Greer-Thorbecke indicies for poverty. The results showed that the higher the liberalisation of rice and agricultural trade, the better off Pakistan's economic welfare and poverty indices were in both the short and long run, with an emphasis on households, specifically farm households.

Another study (Ralf \& Vanzetti, 2012) focused on Mexico, which went through various trade reforms that resulted in high poverty and unemployment rates and high imports. The research highlights the association between NAFTA and lowered agricultural output from Mexico, which consequently affects the other previously mentioned economic factors. A CGE model was used to test the effect of alternative policies that protect the agricultural sector and observe the outcome on welfare, trade, and production. The results showed that increasing the distortion would improve the output, employment, and exports of the agricultural sector, but would have an opposing effect on the rest of the economy.

Zaki (2010) attempted to model trade facilitation of the world economy in a dynamic CGE model with a multi-regional and multi-sectoral model (MIRAGE). The model adjusts the ad valorem equivalents. The results showed that mainly Africa and Asia, specifically the Middle East and North Africa, benefited from the facilitation more than developed regions. 
Finally, Diao and Somwaru (2000) used an intertemporal global multi-sector general equilibrium model to test the dynamic effects of the Free Trade Area of the Americas (FTAA) on countries in the western hemisphere. The researchers used a CGE model to observe the effects on savings-investment, and capital accumulation and the correlation between trade liberalisation and economic growth. The results show that welfare does not change when trade is largely done with countries outside the western hemisphere; all developing countries in the region will yield welfare gains. The results also show that the FTAA's effects on the US and Canada are low; nevertheless, the US and Canada do seem to retain a strong motive to invest in nearby countries.

\section{The Model Specifications}

In this study, the CGE model will be used to calculate Egypt's welfare, and the proxy used to represent welfare is the equivalent variation. The database used is the Social Accounting Matrix (SAM), which includes information about the Egyptian economy in terms of the flows of goods and services in a benchmark year (2007). The matrix was calibrated by the Global Trade Analysis Project, which contains the aggregate values for the Egyptian economy and activities (Burfisher, 2021). The main reason behind choosing this method is its ability to work efficiently on developing countries. Unlike econometric techniques, which need structured models with comprehensive data, CGE can cope with inaccessibility and inconsistency of data reflecting changes in the economy (Bandara, 1991). It is an empirical analysis tool that reflects the effect on the aggregate welfare and the impact of a policy change through various markets with different combinations of tax subsidies and other tools (Wing, 2004).

The basis of a CGE model is the circular flow of commodities, as it helps identify the main agents within the model and the role of each and therefore assesses their behavior. The base model is shown in Figure 1. After setting the flow of the agents in the economy and the main actors influencing that flow, an understanding of the endogenous and exogenous variables (model closure) is necessary, and the rules of the game (whether the players are price takers or givers) must be identified (Burfisher, 2021).

FIGURE 1

\section{CIRCULAR FLOW DIAGRAM OF ECONOMY AGENTS}

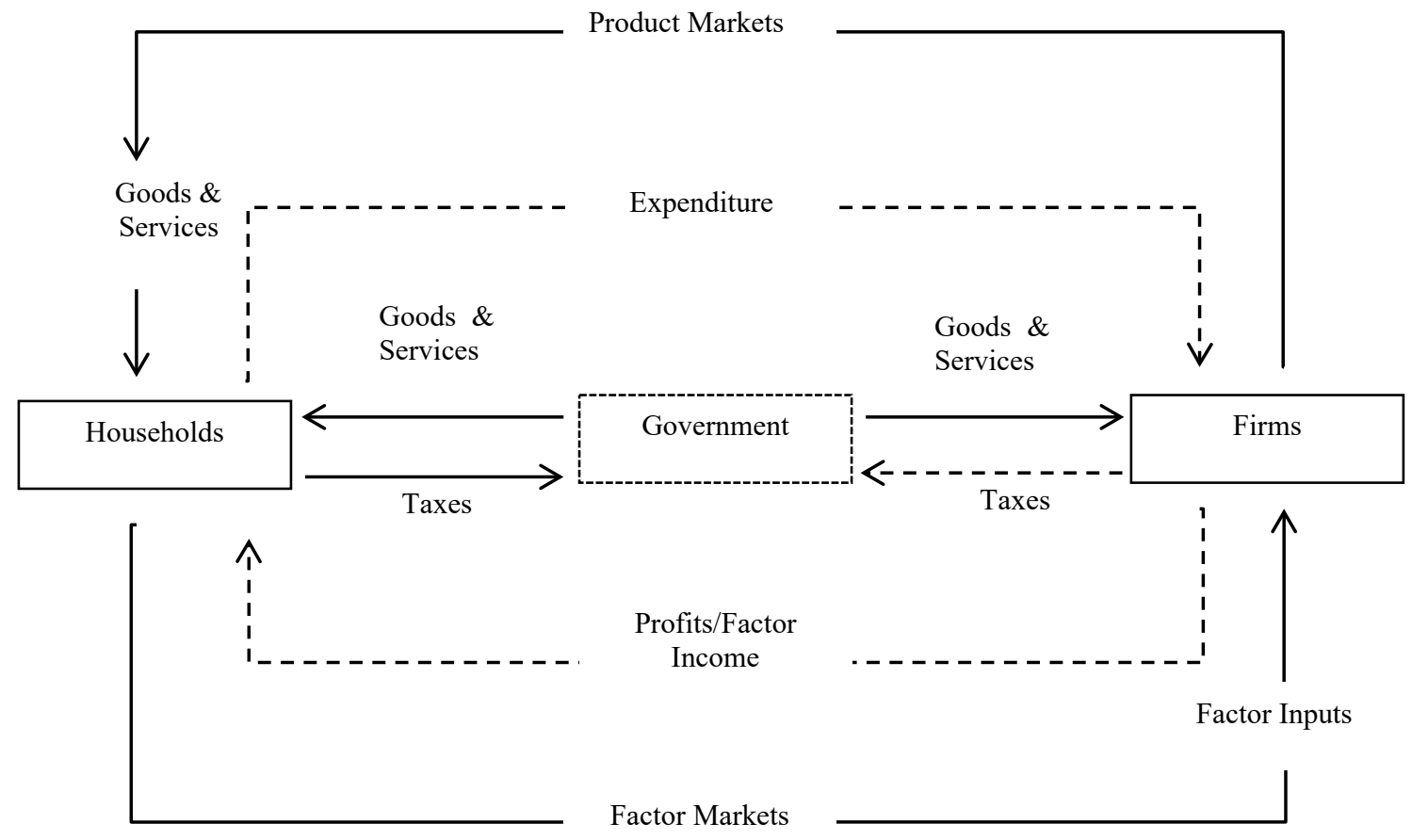

Source: Wing's (2004) Computable General Equilibrium Models and their Use in Economy-Wide Policy Analysis 
Then, equations derived from economic theory are used to describe the economy at market clearing conditions (aggregate supply equals aggregate demand) for each market, zero profit for producing firms, and income balance (the flow of income and expenditure are equal). In other words, these equations are solved simultaneously, given that a change in an exogenous variable is made and the model is resolved, and new values for the endogenous variables are generated, which will help understand the effect of the change on the economy (Burfisher, 2021).

The CGE model is a neo-classical one with an open economy for three regions: Egypt, the European Union (EU), and the Rest of the World (ROW). The production activities in the economy are aggregated into three sectors: Agriculture, Manufacturing, and Services, with three factors of production: Land, Labour, and Capital. The factors of production have a Leontief fixed proportions production function, wherein the factors are perfect compliments for each other, in addition to a Constant Elasticity Substitution (CES), wherein the factor substitution elasticity is constant at 1 . The three factors of production are given full mobility within the model (Burfisher, 2021; Feraboli, 2007).

Currency is neutral and normalized because Egypt is a price taker with no effect on world price (Zaki, 2010). As for production activity, perfect competition is assumed, and a Cobb Douglas nested production function will be the mould for the model, with the three sectors incorporated within the production function. Demand will use an Armington import aggregation function, where the preference of domestic vs. foreign goods will be decided according to the relative price of the goods. This will minimize their costs and maximize the utility given their income constraint. Having that said, demand will also have CES attributes (Burfisher, 2021).

The equations used for the CGE assumptions to explain the demand and supply sides based on the CES attributes and the market closure are as follows (Gohin \& Hertel, 2003):

\section{Conditional Demand (Demand Side)}

$$
\begin{aligned}
& \hat{x}_{1}=\hat{y}+\sigma\left(\hat{\delta}_{1}+\hat{c}_{y}-\hat{p}_{1}\right)+(\sigma-1) \hat{\alpha} \\
& \hat{x}_{2}=\hat{y}+\sigma\left(\hat{\delta}_{2}+\hat{c}_{y}-\hat{p}_{2}\right)+(\sigma-1) \hat{\alpha}
\end{aligned}
$$

- $\quad x_{1}$ and $x_{2}$ are the input levels, and $p_{1}$ and $p_{2}$ are their market prices

- $y$ is the production level

- $\quad \propto$ is the efficiency parameter, with $\propto>0$

- $\delta_{1}$ and $\delta_{2}$ are distribution parameters

- $\sigma=\frac{1}{1+\rho}$, the constant elasticity of substitution, with $\rho>-1$

- The hat ${ }^{\wedge}$ represents proportional changes (if change is to the first degree)

- The demand side equations show how a change in relative prices on conditional demand is a function of a change in unit cost with respect to the own price of the input.

\section{Unit Cost Function (Supply Side)}

$$
\hat{c}_{y}+\widehat{\propto}=\theta_{1}\left(\frac{\hat{\delta}_{1}}{\rho}+\hat{p}_{1}\right)+\theta_{2}\left(\frac{\hat{\delta}_{2}}{\rho}+\hat{p}_{2}\right)
$$

- $\propto$ is the efficiency parameter, with $\propto>0$

- $\delta_{1}$ and $\delta_{2}$ are distribution parameters

- $p_{1}$ and $p_{2}$ are prices of the two goods

- $c_{y}$ is unit cost

- $\rho$ is elasticity of substitution with $\rho>-1$ 
- $\theta$ is cost shares

- The hat ${ }^{\wedge}$ represents proportional changes (if change is to the first degree)

- The equation takes into account that the unit cost depends on technical and the two price. It also matches the zero-profit condition.

\section{Description of Scenarios}

The E-EUAA agreement terms will be exhibited in this paper by playing with the tariff rates of imports entering Egypt in three different scenarios. Each scenario examines the agricultural and industrial reforms applied (EU Agreement, 2004).

The magnitude of change in tariff rates in the simulation is determined according to the E-EUAA so that there is a gradual decrease in the rates for each scenario until all rates are demolished. On the other hand, all imports to the EU from Egypt, whether agricultural or industrial, will have a $0 \%$ rate according to the execution of the agreement.

According to Burfisher (2021), unemployment is a serious problem that cannot be ignored. In order to reflect more realistic outcomes, Egypt's 15\% unemployment rate (as of 2019) cannot be ignored; full employment is not good enough to reflect the Egyptian reality. Therefore, an unemployment shock was added to the model for both countries: the unemployment rate was set to $15 \%$ for Egypt and $9.6 \%$ for the EU (Burfisher, 2021; World Databank, 2020).

TABLE 1

\section{MODEL SCENARIOS}

\begin{tabular}{|c|c|c|c|}
\hline Type of Reform & Scenario 1 & Scenario 2 & Scenario 3 \\
\hline $\begin{array}{l}\text { Egypt Agricultural Reform } \\
\text { Import Tariffs on EU agricultural imports to } \\
\text { Egypt }\end{array}$ & $\begin{array}{l}\text { Decrease by } \\
5 \%\end{array}$ & $\begin{array}{l}\text { Decrease by } \\
25 \%\end{array}$ & Set to $0 \%$ \\
\hline $\begin{array}{l}\text { Egypt Manufacturing Reform } \\
\text { Import Tariffs on EU manufacturing imports } \\
\text { to Egypt }\end{array}$ & $\begin{array}{l}\text { Decrease by } \\
50 \%\end{array}$ & $\begin{array}{l}\text { Decrease by } \\
75 \%\end{array}$ & Set to $0 \%$ \\
\hline $\begin{array}{l}\text { EU Agricultural Reform } \\
\text { Import Tariffs on Egyptian agricultural } \\
\text { imports to EU }\end{array}$ & Set to $0 \%$ & Set to $0 \%$ & Set to $0 \%$ \\
\hline $\begin{array}{l}\text { EU Manufacturing Reform } \\
\text { Import Tariffs on Egyptian manufacturing } \\
\text { imports to EU }\end{array}$ & Set to $0 \%$ & Set to $0 \%$ & Set to $0 \%$ \\
\hline
\end{tabular}

\section{SIMULATION RESULTS}

The simulation results are divided into three scenarios: the first has the highest protectionism while the third has the least. The base represents the tariff rates before the EG-EU agreement. Within each scenario, the outcome is expressed through the total impact, tariff impact, and unemployment impact; this will help assess the effect of each factor individually.

In all three scenarios, the Egyptian economy welfare has a negative value. This reflects a decrease from the base run (Burfisher, 2021), which could be attributed to the increasing prices of goods and declining quantities as shown in Table 2. The welfare (equivalent variation) and the trade balance are expressed in \$USD mil., while the rest of the variables are expressed in terms of percentage change. 


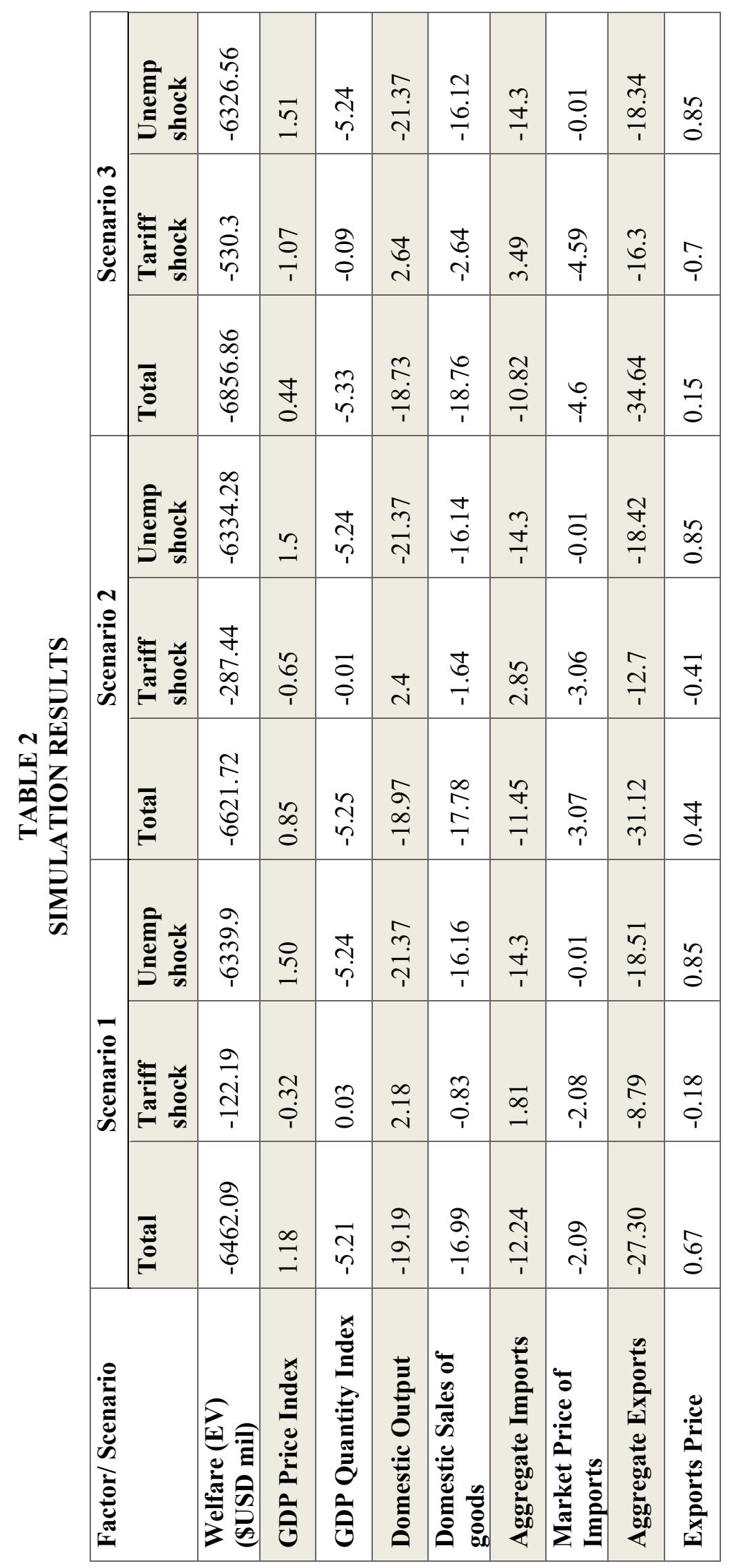


Investigating the impact of imposing a tariff on the variables reveals that the tariff caused a fall in welfare, GDP, domestic output, domestic sales, aggregate imports, import prices, and aggregate exports, and an increase in prices (increased inflation), export prices, and the trade balance.

The decrease in the welfare is understandable considering the fall in GDP and increase in prices (inflation). The fall in GDP may be attributed to the decrease in the domestic output, which also affected domestic sales.

However, looking at the effect of tariffs on the model, the liberalisation of tariffs caused the welfare to decrease almost by $6.1 \%$ from the initial run.

Economic welfare is affected by changes in the quantity and prices of goods (Varian, 2010). This becomes apparent when looking at the output for the GDP price index, which represents inflation; it shows a $62.7 \%$ decrease in the levels of inflation as the tariffs fall from the initial run. The tariff shock causes a decrease to the rates, which escalates as the tariffs approach $0 \%$.

On the other hand, the GDP quantity index decreases, which explains the welfare outcome. This change could be attributed to the increase in prices of goods and services. The decrease in tariffs rate resulted in a $2.3 \%$ decrease in the quantity of goods in the GDP.

When assessing the elements concerned with demand on goods and services, three components are considered: domestic output, labor demand, and domestic sales of goods. Domestic output increased by $2.39 \%$, which is mainly influenced by the tariff shock. As for the labor demand, although the effect of unemployment counterbalances the positive values yielded by the tariff, the total value exhibits an increase as liberalisation increases. This increase in labor demand is due to the increase in the domestic output. On the other hand, the domestic sale of goods decreases from the base run and continues to decrease as tariffs approach zero by $10.42 \%$.

The last three components represent trade output. Aggregate imports increased by $11.6 \%$ with the liberalisation of trade. The tariff shock has a positive impact, accounting for almost $14.7 \%$; thus, it caused the increase in the change of aggregate imports. The decrease in market price of imports justifies the increased import demand, which, given that import demand substitution is elastic, is unaffected by unemployment.

As far as exports are concerned, demand and prices decreased by almost $26.9 \%$, and this decrease was mainly a result of the decreased tariffs. The price of exports increases from the base run, hence the positive value. However, as the tariff rate decreases and approaches zero, export prices also decrease. On the other hand, the aggregate exports also decrease. The decreased prices are lower than the base run and continue to deteriorate as the tariff rate falls, which may be attributed to the insufficient quality of Egyptian exports. The quality of exported goods is not a novel topic; indeed, the World Bank Middle East Studies Report argued that Egypt needs world-class goods capable of international competition, a skilled labor force, and relative export prices (Yang, 1998).

\section{CONCLUSION AND POLICY IMPLICATIONS}

The main purpose of the study was to explore the effect of protectionism on small countries that have no influence over world price, using Egypt as a case study. The results showed that the economic welfare increases as protectionism increases.

By using the E-EUAA agreement terms, this study showed that implementing different tariff rates that eventually arrive at zero helps decrease aggregate exports, which causes a fall in the GDP, which eventually results in the deterioration of the welfare of the Egyptian economy. The outcome of the decreasing exports is quite interesting: the price of exports fell, which may imply that demand for Egyptian exported goods poses a problem. This may be due to the lack of high-quality goods in the Egyptian market resulting in an inability to compete internationally, therefore affecting the GDP; this has been suggested by previous literature.

This outcome partially contradicts that of Cockburn (2001); in the case of Nepal, eliminating tariffs caused the country's welfare to increase, but only in urban areas, while it decreased in rural areas to a 
significant magnitude. However, the result matched that of Konan and Maskus (2000), who also focused on Egypt and found that the liberalisation of trade caused distortions in the welfare.

These results highlight the effect of unemployment on the economy. The high rates of unemployment did not change the direction of impact, regardless of the tariff rate; nevertheless, the magnitude was significant enough to affect the total impact value, especially welfare, labor demand, change in trade balance, and aggregate imports. Also of emphasis are the distortions in the economic welfare that may occur due to tariff rate changes and trade liberalisation, even while small developing countries have no influence over world prices.

The study highlights some outcomes for policymakers when it comes to tariff reduction or elimination. In the case of Egypt, special strategies are needed to liberalize trade, starting with the quality of the Egyptian goods available for export and encouraging domestic production. This could mean that the infant industry argument holds true when it comes to Egypt as a small developing country. Recommendations for future research include using a dynamic model to further investigate the effect of trade liberalisation policies on the long run with different shocks to the model, including government subsidies, to see the counteracting effect of the tariffs. Further informative outcomes could be achieved by using a more recent SAM or a sample of different developing countries from different areas.

\section{ACKNOWLEDGEMENTS}

I would like to sincerely thank my mentor, Associate Professor Dr. Hebatallah Ghoneim, for without her consistent encouragement and support this work would have never been done. I would also like to dedicate this to my mother, for always believing in me; my daughters, for giving me all the love; my sisters, for their endless care; and soon to be Dr. Noha Ghazy, for being by my side during all the mischief.

\section{REFERENCES}

Adegboye, F., Matthew, O., \& Ejemeyovwi, J. (2020). Assessing the Role of Trade Liberalisation in Facilitating Trade Flows and Economic Expansion: Evidence from ECOWAS Countries. In Fostering Trade in Africa.

Altschiller, D. (1988). Free Trade Versus Protectionism: The Reference Shelf. New York: The H.W. Wilson Company.

Bandara, J. (1991). Computable General Equilibrium Models for Development Policy Analysis in LDCs. Journal of Economic Surveys, 5(1), 3-69.

Braga de Macedo, J., \& Martins, J. (2006). Growth, Reform Indicators and Policy Complementaries. NBER working Paper Series.

Burfisher, M. (2021). Introduction To Computable General Equilibrium Models. New York: Cambridge University Press.

Cockburn, J. (2001). Trade Liberalisation and Poverty in Nepal: A Computable General Equilibrium Micro Simulation Analysis. Centre for The Study of African Economies and Nuffield College.

Diao, X., \& Somwaru, A. (2000). A Dynamic Evaluation of the Effects of a free Trade Area of the Americas - An Intertemporal, Global General Equilibrium Model. GTAP Working Papers.

Elshennawy, A. (2012). The Euro-Mediterranean Free Trade Agreement and the Cost of Tariff Liberalisation in Egypt. Journal of Policy Modeling.

EU Agreement. (2004). Euro Mediterranean Agreement, Establishing an Association Between Communities and Their Members States, of the One Part, and the Arab Republic of Egypt, of the Other Part.

Fahmy, N. (2012). Egypt in the World. Cairo: The American University in Cairo.

Feraboli, O. (2007). Preferential Trade Liberalisation, Fiscal Policy Responses and Welfare: A Dynamic CGE Model for Jordan. Jahrbucher f. Nationalokonomie u. Statistik, 227(4).

Gohin, A., \& Hertel, T. (2003). A Note on the CES functional form and its use in the GTAP model. GTAP Research Memorandum No. 2. 
Ikram, K. (1980). Egypt: Economic Management in a Period of Transition. Baltimore: The John Hopkins University Press.

Konan, D., \& Maskus, K. (2000). Joint trade liberalisation and tax reform in a small open economy: The case of Egypt. Journal of Development Economics.

Krugman, P., Obstfeld, M., \& Melitz, M. (2015). International Trade: Theory and Policy. In P. Krugman, M. Obstfeld, \& M. Melitz, International Trade: Theory and Policy (pp. 300-308). Essex: Pearson.

Mankiw. (2009). Macroeconomics. New York: Worth.

Noll, R. (1997). The International Dimension of Regulatory Reform: With Applications to Egypt. Distinguished Lecture Series of the Egyptian Center for Economic Studies.

Ralf, P., \& Vanzetti, D. (2012). A Coherent Agriculture Trade Policy for Mexico. 5th Annual Conference on Global Economic Analysis. Geneva.

Salvatore, D. (2020). International Economics. Hoboken: Wiley.

Siddiqui, R. (2007). A GCE Analysis of Global Rice and Agricultural Trade Liberalisation: Welfare and Poverty Implications for Pakistan. Research Gate. Retrieved 2018, from https://www.researchgate.net/publication/265409203_A_CGE_Analysis_of_Global_Rice_and_A griculture_Trade_Liberalisation_Welfare_and_Poverty_Implications_for_Pakistan

Varian, H. (2010). Intermediate Microeconomics. New York: W. W. Norton and Company.

Wing, I.S. (2004). Computable General Equilibrium Models and Their Use in Economy - Wide Policy Analysis. MIT Joint Program on the Science and Policy of Global Change. Cambridge.

World Databank. (2020). Retrieved March 15, 2018, from http://databank.worldbank.org/data/ views/variableselection/selectvariables.aspx?source=worlddevelopment-indicators

Yang, C. (1998). Egypt in The Global Economy: Strategic Choices for Savings, Investments and Long Term Growth. World Bank Middle East and North Africa Studies.

Zaki, C. (2010). Towards an Explicit Modeling of Trade Facilitation in CGE Models: Evidence From Egypt. Working Paper Series of The Economic Research Forum.

Zaki, C. (2010, April). A Global Assessment of the Trade Facilitation Effects: The Case of MIRAGE Model. GTAP Working Papers. 